\title{
POLA KEKERASAN PADA KORBAN KEJAHATAN SEKSUAL YANG MENINGGAL DAN DI PERIKSA DI RSUP PROF. DR. R . D. KANDOU MANADO
}

\author{
Angelique Pongoh
}

Johannis Mallo

James Siwu

\author{
Bagian Ilmu Kedokteran Forensik Medikolegal Fakultas Kedokteran Universitas Sam \\ Ratulangi Manado
}

Email: angelique.pongoh@gmail.com

\begin{abstract}
Violence act or behavior is a condition in which individual does or attack another or environment. The violence with sexual harassment includes: flirt, rouge whistling, comment connoting sex, porn humor, pinch, poke, pat or touch on certain body parts, certain movements or sexual signals, dating invitation with threats, and sexual solicitation to sexual rape. In the examination of dead victims of sexual crimes it is often found that the violence occured on the victim's body. This research aims to help doctors and medical staff to be able to know the pattern of violence on the dead victims caused by sexual crimes and to perform the Visum Et Repertum on each victim properly, and also to help the investigators to establish the severity of the punishment on the perpetrators of sexual crimes in Manado. The research design is a cross sectional description taking secondary data from medical records at BLU SMF Prof.Dr. R. D Kandou hosptal, Manado. The pattern of violence found in this research shows that in fact the area of body that often happens crimes causing by sexual violence is at the head and neck parts (42.1\%) and extremities (38.1\%).
\end{abstract}

Keyword: Sexual harassment, victim, violence

Abstrak:Tindakan kekerasan atau perilaku kekerasan adalah suatu keadaan dimana individu melakukan atau menyerang orang lain atau lingkungan. Adapun kekerasan dengan pelecehan seksual, meliputi: main mata, siulan nakal, komentar yang berkonotasi seks, humor porno, cubitan, colekan, tepukan atau sentuhan di bagian tubuh tertentu, gerakan tertentu atau isyarat yang bersifat seksual, ajakan berkencan dengan ancaman, ajakan melakukan hubungan seksual sampai perkosaan. Dalam pemeriksaan korban mati dengan kejahatan seksual sering didapati kekerasan - kekerasan yang terjadi di tubuh korban. Penelitian ini bertujuan untuk membantu para dokter dan tenaga medis agar dapat mengetahui pola kekerasan pada korban mati karena kejahatan seksual dan agar setiap dokter dapat melaksanakan Visum Et Repertum pada setiap korban dengan baik dan benar, serta dapat membantu para penyidik untuk menegakkan berat ringannya hukuman pada pelaku kejahatan seksual di Manado.Desain penelitian ini bersifat deskriptif cross sectional mengambil data sekunder dari rekam medis di SMF BLU RSUD Prof.Dr. R. D Kandou Manado. Pola kekerasan yang didapati pada penelitian ini menunjukan bahwa ternyata daerah pada tubuh yang sering terjadi kekerasan karena kejahatan seksual ialah pada daerah kepala dan leher $(42,1 \%)$, dan ekstrimitas $(38,1 \%)$. Kata Kunci: Pelecehan seksual, korban, kekerasan

Perilaku kekerasan adalah suatu keadaan dimana seseorang melakukan tindakan yang dapat membahayakan secara fisik baik terhadap diri sendiri, orang lain maupun lingkungan. Marah merupakan perasaan jengkel yang timbul sebagai respon terhadap kecemasan / kebutuhan yang tidak terpenuhi yang dirasakan sebagai ancaman. Perilaku kekerasan adalah suatu kondisi maladaktif seseorang dalam berespon terhadap marah. Tindakan kekerasan / perilaku kekerasan adalah suatu keadaan dimana individu melakukan atau menyerang orang lain / lingkungan. Tindak kekerasan 
merupakan suatu agresi fisik dari seseorang terhadap yang lainnya. Dari beberapa pengertian tersebut dapat ditarik suatu kesimpulan bahwa perilaku kekerasan atau tindak kekerasan merupakan ungkapan perasaan marah dan bermusuhan yang mengakibatkan hilangnya kontrol diri dimana individu bisa berperilaku menyerang atau melakukan suatu tindakan yang dapat membahayakan diri sendiri, orang lain, dan lingkungan. ${ }^{1}$ Kekerasan terhadap perempuan merupakan fenomena sosial yang telah berlangsung lama dari masyarakat yang masih primitif sampai pada masyarakat modern sekarang ini. Berbagai tindak kekerasan telah dialami oleh perempuan dari sewaktu - kewaktu, banyak faktor faktor yang melatar belakangi timbulnya tindak kekerasan terhadap perempuan, diantaranya faktor budaya, faktor sosial, dan faktor ekonomi. ${ }^{2}$ Adapun kekerasan dengan pelecehan seksual, meliputi: main mata, siulan nakal, komentar yang berkonotasi seks, humor porno, cubitan, colekan, tepukan atau sentuhan di bagian tubuh tertentu, gerakan tertentu atau isyarat yang bersifat seksual, ajakan berkencan dengan iming-iming atau ancaman, ajakan melakukan hubungan seksual sampai perkosaan.Pelecehan juga dapat berupa komentar/perlakuan negatif yang berdasar pada gender, sebab pada dasarnya pelecehan seksual merupakan pelecehan gender, yaitu pelecehan yang didasarkan atas gender seseorang, dalam hal ini karena seseorang tersebut adalah perempuan. Seperti: " Tugas perempuan kan di belakang....", "Tidak jadi dinikahi, karena sudah tidak perawan lagi....".Pelecehan seksual bisa terjadi di mana saja dan kapan saja, seperti di bus, pabrik, supermarket, bioskop, kantor, hotel, trotoar, dsb baik siang maupun malam.Pelecehan seksual di tempat kerja seringkali disertai dengan janji imbalan pekerjaan atau kenaikan jabatan. Bahkan bisa disertai ancaman, baik secara terang-terangan ataupun tidak. Kalau janji atau ajakan tidak diterima bisa kehilangan pekerjaan, tidak dipromosikan, dimutasikan, dsb. Pelecehan seksual bisa juga terjadi tanpa ada janji atau ancaman, namun dapat membuat tempat kerja menjadi tidak tenang, ada permusuhan, penuh tekanan, dsb. Hampir semua korban pelecehan seksual adalah perempuan tidak memandang status sosial ekonomi, usia, ras, pendidikan, penampilan fisik, agama, dsb. Korban pelecehan akan merasa malu, marah, terhina, tersinggung, benci kepada pelaku, dendam pada pelaku, shock, trauma berat, kerusakan organ fisik, dll. ${ }^{3}$ Yang dimaksud dengan pemerkosaan adalah "seorang pria yang memaksa pada seorang wanita bukan istrinya untuk melakukan persetubuan dengannya dengan ancaman kekerasan, yang mana diharuskan kemaluan pria telah masuk ke dalam lubang kemaluan seorang wanita dan yang kemudian mengeluarkan air mani". ${ }^{4}$ Perbuatan pemerkosaan merupakan seks bebas (freeseks) di luar nikah yang merugikan pihak lain, yang diperkosa. Perbuatan pemerkosaan dilakukan dengan kekerasan karena bukan didasari suka sama suka. Umumnya pemerkosaan dilakukan laki - laki terhadap perempuan. Pelaku pemerkosaan bisa satu,dua atau lebih. Bila pelaku lebih dari satu orang, korban digilir tanpa pengasihan. Biasanya setelah diperkosa korban ditinggalkan begitu saja. ${ }^{5}$ Pembuktian tindak pidana pemerkosaan di pengadilan sangatlah tergantung sejauh mana penyidik dan penuntut umum mampu menunjukan bukti-bukti bahwa telah terjadi tindak pidana pemerkosaan. Harus diakui pembuktian dalam tindak pemerkosaan adalah sangat sulit, sebab pihak yang berwenang harus memastikan benar apakah perbuatan pemerkosaan tersebut dilakukan dengan kekerasan atau ancaman kekerasan. Oleh karena itu untuk membantu para penegak hukum mengungkap suatu masalah kekerasan diperlukan bantuan dokter. Tugas pokok seorang dokter dalam membantu pengusutan tindak pidana terhadap kesehatan dan nyawa manusia ialah dengan pembuatan Visum Et Repertum dengan mengumpulkan kenyataan-kenyataan dan menghubungkannya satu sama lain secara logis untuk kemudian mengambil kesimpulan. Maka, oleh karenanya pada waktu memberi laporan pemberitaan dari Visum Et Repertum itu harus yang sesungguh-sungguhnya dan seobyektifobyektifnya tentang apa yang dilihat dan ditemukannya pada waktu pemeriksaan. ${ }^{6.7}$ Dokter dengan pengetahuan ilmu forensiknya sangat dibutuhkan dalam menentukan kualifikasi luka sebagaimana tertuang dalam: Visum Et Repertum. Dimana Visum Et Repertum itu sangat diperlukan untuk mencari kejelasan, kebenaran, dan pembuktian-pembuktian materil yang selengkap-lengkapnya tentang suatu perbuatan tindak pidana. Khususnya didalam kasus perlukaan sebagaimana dimaksudkan dengan penganiayaan yang mengakibatkan luka-luka dalam K. U. H. P, dimana sumbangan tersebut diluangkan dalam bentuk Visum Et Repertum, seperti :

\footnotetext{
Menentukan identitas

Menentukan jenis luka

Menentukan jenis kekerasan yang menyebabkan luka

Menentukan kualifikasi luka. ${ }^{6}$
} 
Khusus untuk menemukan kualifikasi luka, dalam hal ini ada 3 kualifikasi luka, yaitu: 1) Luka yang tidak mengakibatkan penyakit. 2) Luka yang mengakibatkan penyakit atau halangan dalam melakukan pekerjaan atau jabatan untuk sementara waktu. 3) Luka yang dimaksudkan dalam K. U. H. P. Pasal $90 .^{7}$ Namun, permasalahan sekarang masih begitu banyak dokter yang belum bisa melaksanakan Visum Et Repertum yang baik dan benar, terutama banyak dokter yang belum bisa mengkualifikasi luka pada korban kekerasan seksual. Sedangkan dalam hal ini dokter sangat dibutuhkan karena dengan kemampuan dokter dalam melakukan kualifikasi luka sangat penting bagi pihak berwajib untuk menentukan berat ringannya, hukuman tehadap tersangka. Karena berat ringannya hukuman terhadap tersangka dilihat dari berat ringannya luka pada korban kekerasan. Maka dalam hal ini kedudukan seorang dokter atau dokter spesialis forensik sangat diperlukan dalam penanganan korban kejahatan seksual, dimana dalam hal ini adalah bantuan profesi dokter akan sangat menentukan adanya kebenaran faktual yang berhubungan dengan kejahatan. ${ }^{7}$ Atas dasar apa yang diutarakan tadi, maka didalam melakukan penyidikan perkara pidana yang menyangkut tubuh, kesehatan, dan nyawa manusia prinsip-prinsip ilmu kedokteran forensik perlu dikuasai oleh setiap dokter. Karena Undang-undang peraturan maupun pihak berwajib tidak dapat menentukan besar kecilnya suatu luka pada korban kekerasan tanpa bantuan dokter. ${ }^{7}$

\section{Metode Penelitian}

Penelitian ini bersifat deskriptif cross sectional mengambil data sekunder dari rekam medis di SMF Kedokteran UNSRAT.Sampel yang diambil ialah semua korban mati yang mellui prosedur pemeriksaan Forensik di BLU RSUD Prof.Dr.R.D Kandou Manado.

\section{Hasil dan Pembahasan}

Hasil yang diperoleh dari penelitian mengenai pola kekerasan pada korban kejahatan seksual di Manado adalah sebagai berikut:

Kasus dengan dugaan kekerasan seksual di SMF BLU RSUD Prof. Dr. R. D Kandou Manado dengan kasus - kasus lainnya. (bagan 1).

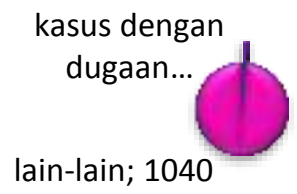

\section{Bagan 1. Proporsi kasus kekerasan seksual di RSUP Prof.dr. R.D Kandou}

Semua korban kekerasan seksual yang diperiksa di RSUP Prof.dr.R. D Kandou pada penelitian ini berjenis kelamin perempuan, dengan tabulasi umur seperti yang tercantum pada tabel 1 .

Tabel 1: Distribusi korban berdasarkan jenis kelamin dan umur

\begin{tabular}{|c|c|c|c|}
\hline Jenis Kelamin & Usia & Usia & Usia \\
& $\mathbf{0}-12$ & $\mathbf{1 3}-21$ & - \\
\hline Laki-laki & - & - & $\mathbf{9}$ \\
\hline Perempuan & $\mathbf{2}$ & $\mathbf{3}$ & \\
\hline
\end{tabular}

Korban yang mengalami kekerasan seksual, pada tubuhnya ditemukan tanda kekerasan mekanik, dengan kekerasan tumpul sebagai kasus terbanyak. Rincian jenis kekerasan yang ditemukan pada tubuh korban dengan dugaan kekerasan seksual dapat dilihat pada tabel 2. 
Tabel 2: Jenis Kekerasan pada tubuh korban

\begin{tabular}{|c|l|}
\hline Jenis Kekerasan & Jumlah \\
\hline$>$ Kekerasan Mekanik: & \\
$-\quad$ Kekerasan Tajam & $\mathbf{3}$ \\
$-\quad$ Kekerasan Tumpul & $\mathbf{1 4}$ \\
$-\quad$ Senjata api & $\mathbf{0}$ \\
\hline$>$ Kekerasan Fisika & $\mathbf{0}$ \\
\hline$>$ Kekerasan Kimiawi & $\mathbf{0}$ \\
\hline TOTAL & $\mathbf{1 7}$ \\
\hline
\end{tabular}

Terdapat berbagai macam jenis luka dan pola luka pada tubuh korban dengan dugaan kekerasan seksual. Untuk mengetahui presentasi daerah terbanyak yang dterjadi luka dapat di lihat pada bagan 2 .

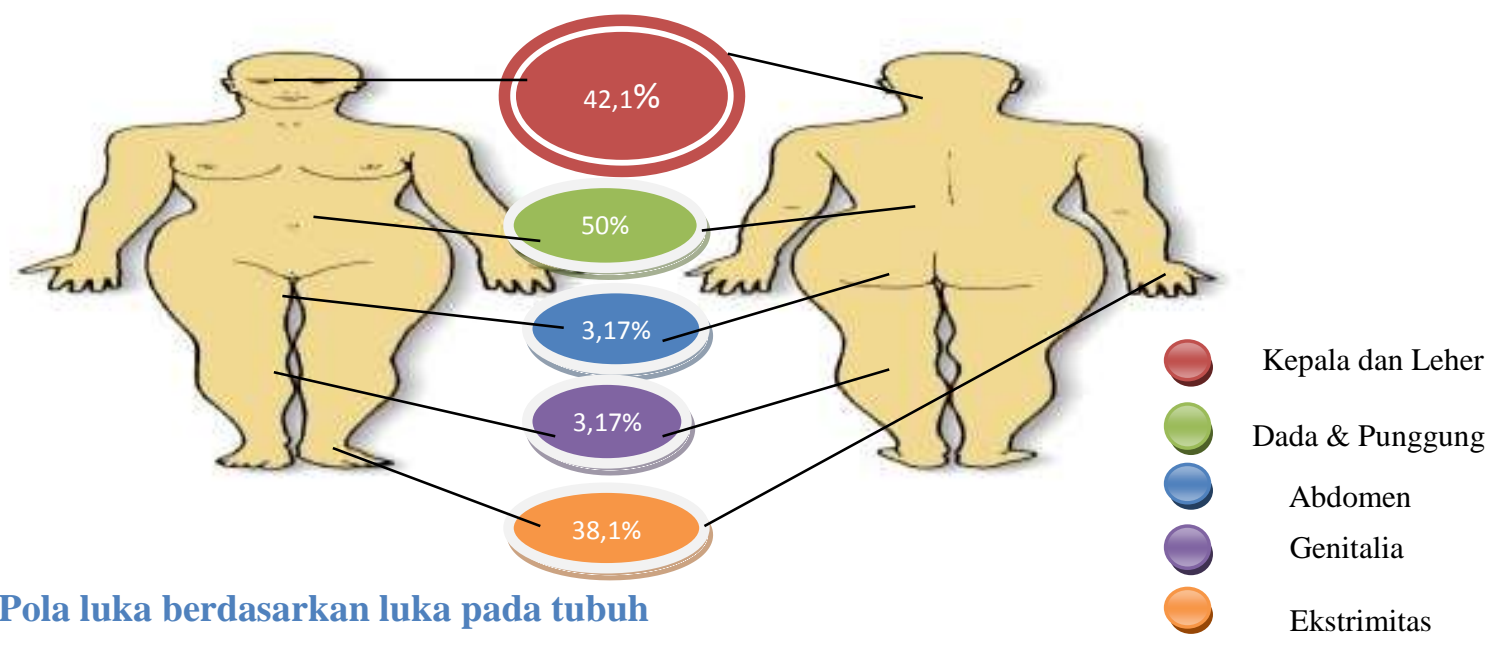

Begitu banyak pola kekerasan yang ditemukan pada tubuh korban dengan kekerasan seksual. Untuk mengetahuinya bisa dilihat pada bagan 3 .

Bagan 3 : Jenis luka yang didapati di tubuh korban dengan dugaan kekerasan seksual

\begin{tabular}{|c|c|c|}
\hline Kepala \& Leher : & 7 & 5,555556 \\
Kepala & 7 & 5,555556 \\
Dahi & 1 & 0,793651 \\
Telinga & 7 & 5,555556 \\
Mata & 9 & 7,142857 \\
Pipi & 4 & 3,174603 \\
Hidung & 6 & 4,761905 \\
Bibir & 2 & 1,587302 \\
Dagu & 10 & 7,936508 \\
Leher & 8 & 6,349206 \\
\hline Dada \& Punggung: & 2 & 1,587302 \\
Dada & 7 & 5,555556 \\
\hline Payudara & & 3,174603 \\
Bahu & 4 & \\
\hline Abdomen: & & 1,587302 \\
Perut & 2 & 1,587302 \\
\hline Genitalia: & 2 & \\
Vagina & 24 & 19,04762 \\
Bokong & 24 & \\
\hline Ekstrimitas: & & \\
Tangan & $\mathbf{1 2 6}$ & \\
Kaki & & \\
\hline Total & & \\
\hline & & \\
\hline
\end{tabular}


Adapun data mengenai berapa banyaknya pemeriksaan mikroskopis dan pemeriksaan dalam yang dilakukan dan tidak dilakukan dalam pemeriksaan pada korban dengan dugaan kekerasan seksual. Dapat dilihat pada bagan 4 dan 5.

\begin{tabular}{|c|c|}
\hline \multicolumn{2}{|c|}{ Pemeriksaan Mikroskopis } \\
\hline YA & TIDAK \\
\hline 9 & 6 \\
\hline
\end{tabular}

Bagan 4 : Data pemeriksaan mikroskopis

\begin{tabular}{|c|c|}
\hline \multicolumn{2}{|c|}{ Pemeriksaan Dalam } \\
\hline YA & TIDAK \\
\hline 13 & $\mathbf{2}$ \\
\hline
\end{tabular}

Bagan 5 : Data pemeriksaan dalam

Data pemeriksaan mikroskopis yang dilakukan pada korban dengan dugaan kejahatan seksual dengan adanya spermatozoa.dapat dilihat pada bagan 6.

\begin{tabular}{|c|c|c|}
\hline \multicolumn{3}{|c|}{ Data pemeriksaan adanya spermatozoa } \\
\hline ADA & TIDAK & Lain-lain \\
\hline 3 & $\mathbf{6}$ & $\mathbf{6}$ \\
\hline
\end{tabular}

Bagan 6 : Data pemeriksaan adanya spermatozoa

Kasus patologi forensik yang terkait dengan kekerasan seksual di RSUP Prof.dr.R.D Kandou mencakup 1,44\% dari seluruh total kasus, dengan rata - rata 3 kasus per tahun. Persentasi kekerasan seksual yang ditemukan pada kasus patologi forensik berbeda dengan persentasi kekerasan seksual pada kasus forensik klinik. Data RSU Bahyangkara tingkat IV tahun 2009 menunjukkan terdapat 283 kasus kekerasan seksual dari 1020 kasus yang ditangani pada tahun 2009. Hal ini menunjukkan bahwa masih kurangnya kasus yang terkait kekerasan seksual yang belum dilaporkan, disisi lain hal ini berarti bahwa kasus terkait kekerasan seksual di Manado masih banyak dengan korban yang hidup.

Korban yang banyak ditemukan dalam penelitian ini berjenis kelamin perempuan saja dengan berbagai macam usia. Tetapi tidak menutup kemungkinan pada daerah lain korban dengan jenis kelamin pria bisa ditemukan dengan berbagai macam usia juga, baik anak - anak maupun dewasa. "93.960 merupakan kasus kekerasan seksual dari total 400.939 kasus kekerasan terhadap perempuan, Sedangkan kasus kekerasan seksual yang terjadi dalam ranah publik adalah kasus kedua terbesar, yaitu 22.284 atau 24 persen dari total 93.960 kasus kekerasan seksual terhadap perempuan," ucap ketua Komnas Perempuan, Yuniyanti Chuzaifah di kantor Komnas Perempuan, Jalan Latuharhary no 4B, Menteng, Jakarta Pusat, Senin (13/2/2012) ${ }^{17}$ Pada penelitian ini korban yang dilaporkan dengan kekerasan seksual saat ini hanya berjenis kelamin perempuan dengan usia tersering dan terbanyak lebih dari 21 tahun. Ini menunjukkan bahwa korban kekerasan seksual yang terjadi di Kota Manado masih bertujuan pada perempuan.

Umumnya kasus kekerasan seksual yang terjadi di ranah publik selalu berkaitan dengan kekerasan-kekerasan lainnya. Berbagai macam jenis kekerasan yang bisa kita temukan pada tubuh korban kekerasan seksual. Dalam penelitian ini ditemukan dua jenis kekerasan yang sering terjadi pada tubuh korban yakni, kekerasan tumpul dan kekerasan tajam. Dimana kekerasan tumpul mendominasi penelitian ini dengan jumlah 14 kali.

Pandangan masyarakat pada umumnya mengenai pola luka pada tubuh korban dengan kekerasan seksual adalah luka pada alat genitalia saja. Namun setelah dilakukan penelitian pola luka pada tubuh korban dengan kekerasan seksual, ternyata presentasi dari luka di sekitar daerah alat genitalia hanya $3,17 \%$ sedangkan presentasi terbesar terdapat pada daerah kepala dan leher sebanyak $42,1 \%$. Ini menjelaskan bahwa pola luka yang bisa terjadi pada korban kekerasan seksual tidak hanya 
terdapat disekitar alat genitalia saja, melainkan dapat ditemukan atau terjadi di daerah mana saja dalam tubuh korban.

Dalam melakukan pemerikasaan korban mati dengan kekerasan seksual harus dilakukan pemerikasaan luar dan dalam untuk mengetahui sebab matinya. Dan untuk memperjelas bahwa korban tersebut mati karena adanya persetubuan atau pemerkosaan harus dilakukan pemeriksaan mikroskopis atau kebidanan. Dan dari hasil penelitian, ditemukan beberapa data yakni dari 15 kasus yang ada, dalam visum et repertum dilakukannya pemerikasaan dalam terdapat 13 kasus, yang tidak 2 kasus dan yang dilakukan pemeriksaan mikroskopis atau pemeriksaan kebidanan sebanyak 9 kasus dan tidak dilakukan terdapat 6 kasus. Dan untuk lebih memperkuat terjadinya persetubuan, dalam melakukan pemeriksaan sediaan langsung apusan vagina yang menunjukkan adanya spermatozoa terdapat 3 kasus dan yang tidak ditemukan sebanyak 6 kasus sedangkan 6 kasus lainnya karena tidak dilakukan pemeriksaan mikroskopis atau kebidanan.

\section{Kesimpulan dan Saran}

Berdasarkan penelitian yang telah dilakukan, maka dapat ditarik kesimpulan dimana kejahatan seksual dapat disertai dengan berbagai jenis kekerasan. Kekerasan adalah penggunaan kekuatan fisik dan kekuasaan, ancaman atau tindakan terhadap diri sendiri, perorangan atau sekelompok orang atau masyarakat yang mengakibatkan memar / trauma hingga kematian. Contoh tersering kekerasan pada korban kejahatan seksual adalah kekerasan tumpul dan kekerasan tajam. Kejahatan seksual dapat terjadi dimanapun dan pada siapapun baik perempuan maupun laki - laki, anak - anak maupun dewasa. Dampak dari kejahatan seksual bisa mengakibatkan masalah psikologis pada korban dan kematian.

Pada korban mati dengan dugaan kejahatan seksual harus dilakukan Visum Et Repertum yang terdiri dari pemerikasaan luar dan dalam serta untuk memastikan terjadinya persetubuan harus dilakukan pemeriksaan kebidanan atau mikroskopis. Adapun mengenai pola luka pada tubuh korban kejahatan seksual, menurut pandangan masyarakat luas bahwa pola kekerasan pada korban kejahatan seksual tersering dan terbesar terdapat pada daerah sekitar genitalia saja namun pada penelitian ini ditemukan bahwa pola kekerasan pada tubuh korban dapat tersebar di berbagai macam daerah pada tubuh korban, dan daerah tersering dan terbesar presentasinya adalah daerah kepala dan leher serta dada dan punggung. Namun tidak menutup kemungkinan juga pada daerah tubuh lainnya.

Pada korban dengan kasus kejahatan seksual perlu dilakukan Visum et Repertum untuk mengetahui sebab pasti dari kematian. Dan dalam melakukan Visum et Repertum pada korban dengan dugaan kejahatan seksual harus disertai dengan pemeriksaan dalam dan pemerikasaan kebidanan maupun pemeriksaan mikroskopis untuk mengetahui adanya persetubuhan.

\section{Daftar Pustaka}

1. Stuart dan Sundeen. Perilaku Kekerasan.1995. Available from: http://digilib.unimus.ac.id/files/disk1/128/jtptunimus-gdl-ipungmdg0a-6384-2-babii.pdf

2. Kholek Abdul. Potret Kekerasan Terhadap Perempuan. Available from: http://www.unsri.ac.id/revolusi_Jalanan/artikel-sosial-budaya/potret-kekerasan-terhadapperempuan/mrdetail/6619/,2010

3. Pustaka Makalah Ilmu Budaya Dasar. Pelecehan Seksual. Available from: http://pustaka-makalah.blogspot.com/2011/03/pelecehan-seksual.html

4. Abdul W, Muhamad I. Perlindungan Terhadap Korban Kekerasan Seksual Advokasi atas Hak Asasi Perempuan, (Malang: Rafika Aditama, 2001 ) ; 40

5. Bgd.Armaidi Tanjung. Free Sex No Nikah Yes, (Jakarta: Amzah,2007) ; 37

6. Dr.Idries AM Sp.F, Dr.Tjiptomartono AL. Penerapan Ilmu Kedokteran Forensik dalam Proses Penyidikan. Edisi revisi. Jakarta, $2008 ; 1-143$

7. Bagian kedokteran forensik ; Fakultas Kedokteran Universitas Indonesia. Ilmu kedokteran forensik. Ilmu kedokteran forensic. Edisi pertama ,cetakan kedua. Jakarta 1997 ; 5 - 16 
